Horizons philosophiques

\title{
Citéphilo 98 : Penser ensemble. Sorties d'utopie
}

\section{Stéphane Boily}

Volume 9, numéro 2, printemps 1999

La philosophie à portée de voix

URI : https://id.erudit.org/iderudit/801132ar

DOI : https://doi.org/10.7202/801132ar

Aller au sommaire du numéro

\section{Éditeur(s)}

Collège Édouard-Montpetit

\section{ISSN}

1181-9227 (imprimé)

1920-2954 (numérique)

Découvrir la revue

Citer ce compte rendu

Boily, S. (1999). Compte rendu de [Citéphilo 98 : Penser ensemble. Sorties

d'utopie]. Horizons philosophiques, 9(2), 87-88. https://doi.org/10.7202/801132ar d'utilisation que vous pouvez consulter en ligne.

https://apropos.erudit.org/fr/usagers/politique-dutilisation/ 


\section{SORTIES D'UTOPIE*}

D'orientation nettement plus politique que philosophique, Sorties d'utopie était plutôt destinée à dresser un bilan général de l'état des institutions financières et politiques des anciennes républiques de l'Est —en particulier la Russie pour M. Kahn après le démantèlement de l'empire communiste.

Piètre bilan hélas, où plus de soixante-dix ans d'un régime morose et avilissant imprègne encore aujourd'hui la grande majorité de ses habitants, en particulier le monde littéraire, scientifique et philosophique.

En effet, si l'érudition et l'intelligence émanant de la communauté intellectuelle de ces pays sont depuis longtemps reconnues, un climat sombre y règne, où l'absence d'initiatives personnelles et la dépendance chronique à l'autorité paralysent en grande partie la volonté de reconstruire une société plus épanouissante à l'aube du troisième millénaire.

Après dix ans, le délabrement général de la structure sociale qui sévit dans ces pays est d'une telle ampleur qu'aucun des spécialistes de la communauté internationale n'avait prévu pareille catastrophe.Malgré des projections économiques enthousiastes et l'espoir d'un système plus «juste» du côté de la population. les propos tenus lors de cette conférence m'ont fait réfléchir sur ce qui m'apparaît comme étant l'obstacle majeur au plein épanouissement de ces pays, soit l'angoisse ressentie devant une liberté soudaine et concrète.

Si la tragédie du communisme enfante encore, dix ans après sa chute, l'incertitude et le chaos dans presque tous les pays ayant subi son joug, la situation risque encore de se prolonger longtemps puisque l'utilisation d'un outil aussi sophistiqué et précieux que la liberté sociale demande à son utilisateur un apprentissage que le communisme, malheureusement, a omis d'inscrire dans le livre de ses illusions perdues.

- Cette conférence a eu lieu le mercredi 18 novembre 1998 au Nouveau Siècle de Lille. Elle était animée par Rose-Marie Lagrave, auteur de Voyages aux pays de l'utopie déchue, Paris : P.U.F., et par Jean-François Kahn, auteur de Tout était faux, Paris : Fayard. 
Ainsi, l'éternel dilemme que provoque la peur et les conséquences du changement reste entier: un retour en arrière ou un pas mal assuré sur les chemins parfois nébuleux de l'histoire?

\section{Stéphane Boily}

